Katarzyna Kruk-Junger (D)

Uniwersytet Pedagogiczny im. KEN w Krakowie katarzyna.kruk-junger@up.krakow.pl

\title{
Analysis of Some Common Misconceptions Regarding the Profession of Liaison Interpreting
}

\section{Professionalisation vs the reality of unprofessional language mediations}

Although some areas of interpreting have already established themselves as professions, the professionalisation of other types is an on-going process. Ever since we realised that to be a translator, "languages are essential, but insufficient. What is needed beyond absolute linguistic proficiency is a perfect knowledge of the relevant cultural, technical, legal, commercial backgrounds, and a full understanding of the subject matter involved" [Gouadec 2007: XVII], both the written translators and interpreters of different kinds have put a lot of effort into making their work recognised and appreciated. It is, however, a complicated path, made even more difficult by the fact that all types of translators and interpreters seem to go through the process from the beginning: what was already achieved in the professionalisation and standardisation of sworn translators or conference interpreters, for instance, does not immediately transfer to other, even similar, fields of work, like technical translations or community interpreting. To make things even more complicated, there is very little 
consensus between the scholars in Translation Studies when it comes to the process of professionalisation itself and the course it should run.

Wolfram Wilss [1999] proposes a threefold development scheme that, first, puts interpreting on the institutional "map" of both international organisations and the public sector, second, implements curricula on the subject to schools and universities, and last, leads to the professionalisation of the market. Małgorzata Tryuk [2007], on the other hand, proposes four stages of professionalisation: 1. analysis of the labour market, 2. creation of the education centres and professional organisations, 3. establishing norms and requirements, certification, and accreditation, and 4. legal regulation regarding the profession. However, probably the most comprehensive vision of professionalisation is the one proposed by Joseph Tseng [1992], who underlines the importance of the unregulated chaos of a market filled with translators and schools that offer education in this area, claiming it is the beginning of any standardisation process. It causes, in consequence, the pressure to establish norms and regulations, which, in turn, results in the creation of organisations that formulate and guard them. All this leads to a number of legal solutions that are to assure the quality of service provided [cited in: Tryuk 2007: 169; Janikowski 2012: 156].

However, this "unregulated chaos" that can be seen now in the area of liaison interpreting has its consequences when it comes to the public perception of what that profession is or should be, and it leads to a widely shared misunderstanding that, in that case, languages are sufficient. Therefore, we would like to argue that one more element should be added to the process of professionalisation of liaison interpreting: promoting the idea that some specific skills and qualifications are needed to perform this task, just as they are necessary in the more established forms of translation and interpreting.

Anthony Pym suggests that a translation done by a professional has an intrinsic value of its own, a value that is desirable and appreciated by the client [2012: 72]:

If a professinal and non-professional both translate A with B, even agreeing on the same range of meaning $\mathrm{B} 1,2,3 \ldots \mathrm{n}$, then the translation will have more value coming from the professional than from the non-professional because the client, the one who's paying, places more trust in the professional. Same text, same work, different value. Professional, we can thus say, sell 
more than a material product: they provide a service whose value comprises relational factors that, judged subjectively, can be more important than the material factors.

Nevertheless, this does not always seem to be the case when it comes to liaison interpreting. There are many interesting examples of situations that contradict this optimistic vision. When in 1977, Jimmy Carter visited Poland, his unqualified interpreter (although, as it was later discovered, qualified translator) caused a stir and embarrassment on a diplomatic level due to his incompetence [see Łępicka 2015]. In the United States, it is still a commonplace occurrence that courts, for many and complicated reasons, employ uncertified interpreters. A problem that remains unresolved, despite pressure from the federal authorities, and leads to many miscarriages of justice [Beitsch 2016]. Moreover, the results of a study conducted in a US hospital show that in more than half of the cases of Spanish-speaking patients, the language intermediaries were unprofessional and uncertified [Flores et al. 2003]. In the latter cases, however, it is hard to argue with the fact that when it comes to professionalisation, community interpreting, as a specific kind of liaison interpreting, is in a worse situation: people who do this type of work usually come from the immigrant population themselves, a fact that does not favour high quality of service provided nor respect towards the practitioners [Wadensjö 1998; Phelan 2001]. The problem, however, is not limited to community interpreters. There are many areas of liaison interpreting, some of them presented in the examples cited below, where hiring unprofessional language mediators is still a commonplace occurrence. The negative consequences of this situation are hard to measure and describe, although many authors, including the ones mentioned above, have tried it. These and other scholars have been waving this particular red flag for years now, and there have been some favourable changes introduced in many countries and in many interpreting contexts, the example of the consistent effort of the Polish Society of Sworn and Specialised Translators (TEPiS) to legalise sworn translators' and interpreters' status being just one of them [see Kubacki 2012]. Yet, there is still a noticeable and general lack of understanding when it comes to the importance of hiring professional liaison interpreters, even in literally life-and-death situations of community interpreting.

However, as mentioned before, although the discussions about both the process of professionalisation and the consequences of unprofessional 
interpreting are an interesting topic, here we would like to analyse the problem from a different angle, i.e., the public presentation of the cases of unprofessional language mediation that can be a direct consequence of the underling idea that anyone who speaks a foreign language can become a liaison interpreter. The cases presented here serve to signal a possible problem with the manner we speak publicly about liaison interpreting: the way these situations are presented in mass media can be called confusing, if not misleading, and possibly influence the process of professionalisation itself.

\section{2. "How does someone this small-minded become a translator?"}

Translator at Japanese marathon under fire for calling African athletes "cute chimpanzees"

Scott Wilson, Feb 16, 2019

On February 3, the "Beppu Oita Mainichi Marathon" was held in Oita Prefecture, part of Japan's southern Kyushu region. One woman in her fifties, whose name has not been made public, volunteered as a translator for the overseas runners who'd been invited to compete.

The woman worked with several athletes from Africa, including Morocco, Ethiopia, Kenya, and South Africa. After the marathon had ended, on February 10 she wrote of her experience on her blog: "It felt like communicating with cavemen," and "They were shy chimpanzees at first, but little by little they opened up." She also captioned a video of her and the athletes with: "Cute chimpanzees."

It wasn't long before her blog post was noticed and reported to the office that had worked with the woman. Her blog has since been closed, but she admitted to making the post, claiming that: "I didn't have any feelings of racism or malicious intent. I regret my thoughtless choice of words."

The office has apologized on her behalf, saying: "The blog post was extremely inappropriate, and we deeply apologize to the athletes and all the people who saw it. We will strive from now on to stress the importance of responsibility to our volunteers, and to educate them."

They have also contacted a representative for the athletes themselves, and are currently discussing the best way to apologize to them as well. 
Here's how Japanese netizens reacted to the news:

"Wow. I'm not sure if she's evil or just stupid."

"How does someone this small-minded become a translator?" "And now the invited athletes probably won't come back because of her."

"I don't understand how you can possibly call someone a 'caveman' or 'chimpanzee' and not have that be malicious intent."

"She says she didn't mean it, but that's even worse. Unintentional discrimination is how racism perpetuates."

"Now everyone in the world will think we Japanese people are like this."

Source: SoraNews 24

The story described in the article occurred in 2019 during a Japanese international marathon and posed some interesting questions about the nature of professionalism. As can be seen, it is unclear whether the woman presented in the article maintained any professional standards while interpreting for the participants. It does not seem to matter. The substance of the accusations put forward is her behaviour after the event, not even in the professional context anymore. The racist comments about "cavemen" and "shy chimpanzees" were posted on her private blog and, supposedly, were her private opinions. Even if we cannot agree with them in any form or shape, we should at least accept that. Nevertheless, the public has spoken: the person in question is not a "good translator." This, however, is not true. Although it would be nice if "small-minded, racist people" did not become translators or, in this case, interpreters, they did not in the case cited above. The woman described here was not an interpreter at all. Calling her, right in the title, a "translator" draws attention to the article but is a misunderstanding. Saying that she "volunteered as a translator" is not any better. The only party that clearly states that the woman was in fact just a typical, general "volunteer" for the event, helping out in the organisational matters, is the organisers themselves, who admitted at the same time that they saw no need to hire interpreters for any language mediations. This, however, does not seem to convince the public opinion, who asks how such an "evil" or "stupid" person becomes an interpreter, throwing shade on the profession as a whole. 
Let us consider for a moment a different scenario. A thought experiment of a kind. If during the same marathon, one of the volunteers helped a participant to find a famous monument or told him the history of the place, would we call them publicly "a guide"? Or "a nurse" if they tended to some injuries? Probably not, because these professions are much more established in society and there is a clear line in our minds that distinguishes "a guide" from a "non-guide," "a nurse" from a "non-nurse." In the case of liaison interpreters, this does not seem to work. For the public at large, everyone who helps to communicate in a foreign language is a "translator." Their qualifications, behaviour, or even whether they were paid or not do not seem to matter, and, as we will see in the following example, this happens on a larger scale as well.

\section{Language mediation and the "Ellen DeGeneres scandal"}

Ellen DeGeneres Called out Over Old Video Showing Her Chastising Young Translator Mid-Interview

By DANIEL S. LEVINE - August 17, 2020 04:30 pm EDT

A controversial video from a 2019 episode of The Ellen DeGeneres Show resurfaced recently, while the show is under investigation for an alleged toxic workplace environment cultivated by senior producers. In the clip, host Ellen DeGeneres criticizes the work of a translator who is trying to help the host communicate with a young musician from Taiwan. The clip is just one of many being re-examined by DeGeneres' critics amid the controversy surrounding her show.

During the 2019 episode, DeGeneres invited the guitarist, Feng E., after he appeared playing ukulele in a viral video. After he performed, DeGeneres sat down with him for an interview, and a young translator was brought on stage. At one point, she asked Feng E. what other instruments he wanted to learn. The translator repeated the question, but it sounded too long for DeGeneres, who stopped her. "Just one question. What else does he want to learn?" DeGeneres repeated as the audience laughed. "I don't know what you're telling him, but just ask him what I'm saying."

The translator apologized and asked the question again. "See? It was that short," DeGeneres said to more laughter. Feng E. said he wanted to learn how 
to use a fingerstyle guitar, which puzzled both DeGeneres and the translator. Someone from the audience said he may have meant an acoustic guitar, which once again caused DeGeneres to criticize the translator. "Don't look at me and go, 'I don't know," DeGeneres said. "We're not having a conversation. I'm asking him what is a fingerstyle guitar." The translator then asked Feng E. to further explain what he meant, but DeGeneres gave up. "Never mind," she said, waving her hands...

Source: popculture.com

In 2019 during a popular talk show hosted by Ellen DeGeneres, the presenter interviewed a young musician from Taiwan, Feng E. A "young translator" was brought in to facilitate the communication, but, unfortunately, failed to do so to the host's satisfaction. The story of the presenter's rudeness toward the girl that was employed to help with the communication and toward the guest was not widely reported until a year later when the celebrity faced accusations of creating a toxic work environment in 2020 [Berg 2020]. Only then the media, including websites, raised the issue of Ms DeGeneres ridiculing the young woman, telling her how to translate and behave, and getting angry at her ineptitude. The fact that she was, in fact, inept cannot be denied: she was, after all, so lost in the translation that a member of the audience had to come to her rescue. That is not to say that the presenter's behaviour was understandable. It was not, unless her show was in no way responsible for facilitating an interpreter for the interview. However, the main problem here is not the fact that the interpreter was incompetent, but rather that the person "hired" for the task (if she was ever paid) was not an interpreter at all. Although the language intermediary described in the article is called "translator," or, at best, "a young translator." analysing the video recording of the interview [Ellen DeGeneres Show season 16, episode 112] reveals that the "interpreter" is very young and seems to still be a minor. Her appearance, clothes and behaviour belong more to a teenager than a woman even in her early twenties. However, since her name does not appear in the episode credits listed on IMDb and the media did not release her name either, these conjectures cannot be easily verified.

What distinguishes this example from the previous one is the possibility that this particular language intermediary could indeed have been hired by 
the show's producers to interpret the interview. That fact, to some extent, would make her a "professional liaison interpreter," if only in the context where the word "professional" designates someone who performs a job for money. Nevertheless, while analysing the video recording of the show, one cannot help to wonder how anyone could associate the young girl's performance with any kind of professional conduct or even a profession. Her age and qualifications notwithstanding, her behaviour alone is a testimony of her lack of professional "aura" of any kind: dressed casually, giggling, chatting with both Ellen and her guest, she acts as if in a friendly social encounter, not in course of performing a paid job. But even so, the mental imperative to call anyone who facilitates the communication between two languages a "translator" takes over, and no amount of evidence can stop the author of the article from using this word while referring to this young person. Again, this creates a wrong public image of the profession as a whole and strengthens the problematic stereotype. The fact that the situation described is a widely discussed one makes it even more troubling. However, the problem of misconceptions is even more complicated, as shown by the next example.

\section{The infamous case of Willie Ramirez}

In the Hospital, a Bad Translation Can Destroy a Life

By Kristian Foden-Vencil - October 27, 2014 4:36 AM ET

Translating from one language to another is a tricky business, and when it comes to interpreting between a doctor and patient, the stakes are even higher. Consider the story of 18-year-old baseball player Willie Ramirez.

In 1980, Ramirez was taken to a South Florida hospital in a coma, says Helen Eby, a certified medical interpreter in Oregon. "His family apparently used the word 'intoxicado' to talk about this person," she says. "Well, 'intoxicado' in Spanish just means that you ingested something. It could be food; it could be a drug; it could be anything that has made you sick."

The family thought something Ramirez had eaten might have caused his symptoms. But the interpreter translated their Spanish as "intoxicated."

"So, the doctor immediately made a diagnosis of drug overdose," Eby says. A couple of days later, the health team figured out that Ramirez's problem was 
actually bleeding in his brain. But by then he'd suffered lasting damage. "The guy ended up quadriplegic," Eby says.

In medical situations, doctors and hospitals often turn to family members for help with interpreting, but that can be problematic, she says.

"You know, you've got a 10-year-old in a gynaecology appointment," she says. "Is this where you would normally take a 10-year-old? Not likely. Or [you'll] have a child - an adult child even - interpret a parent's cancer diagnosis. That's got to be highly traumatic." And the chance that important medical details will be misunderstood increases significantly...

Source: NPR News

No analysis of the so-called "unprofessional interpreting" would be complete without the Willie Ramirez's story. The situation described in the article cited above took place in 1980 and was (and still is) widely discussed both in media and scientific worlds as an example of consequences of using unqualified language intermediaries in medical contexts, which, in this case, include the patient becoming quadriplegic and an indemnification for malpractice that reached \$71 million [Price-Wise 2008]. The article tackles the problem of using family members and other unqualified people's help in communication, which, in itself, is praiseworthy. In doing this, however, the author puts into the same category concepts that do not necessarily belong in one group: the importance of hiring a highly qualified interpreter in a medical context, using children and other family members as language mediators, and - and that is the substance of the described case - not using any language intermediary at all on the assumption that the doctor's level of foreign language proficiency is sufficient. Although the solution to all of these problems is the same, i.e., hiring a professional interpreter (or, simply put, an interpreter), the fact that they all appear in a text describing this medical mistake is problematic, especially considering the main issue leading to this error: there was no interpreter provided, qualified or not, nor there was a helpful bilingual family member present [Price-Wise 2008]. The situation involved no translation whatsoever. There was no "third party" present to convey the message from language A to B. So, why is this particular case used over and over again in the media and other discussions as a typical example of "interpreting mistake"? 
In the article cited above, the author insists that the imaginary translator was present, and that is not in any way an exception when it comes to telling the story by the media. In this case, the mental category of "interpreting" was awarded to the interaction because it happened between the representatives of two different cultures, and because a fatal misunderstanding occurred as a result. There is no argument about the fact that interpreters should be hired by hospitals and other organisations to avoid this kind of tragedies. There is no argument that children and family members should not help during medical exams. All of these issues are important and worthy of repeating. But it is equally important to stop spreading misconceptions about what an interpreter mediated event is. Because these misconceptions do spread. A web page that advertises itself as a "bilingual English-Spanish blog on issues important to the professional interpreter" features the following comment regarding the Willie Ramirez case [The Professional Interpreter 2015]:

At the time of admission, an interpreter made a mistake and translated the Spanish term "intoxicado" which means poisoned or having an allergic reaction as: "intoxicated." Willie, who was suffering from an intercerebral hemorrhage was only treated for an intentional drug overdose. As a result, he was left quadriplegic.

That leads to a conclusion that interpreters themselves fall into the same trap as the rest of the public: a trap of common misunderstandings, misconceptions, and mental shortcuts. If liaison interpreters, as a profession, aspire to the same automatic recognition that other highly qualificationoriented occupations already have, that is a problem.

\section{Conclusions}

The three examples presented above are only a small representation of a tendency that can be noticed in the media coverage of bilingual communication, in which the words "interpreter" or "translator" are used erroneously in cases where an accidental language intermediary was used or even no mediator was present at all. All the cases like the ones analysed here may be supplemented with a significant number of others, where the insinuation of a real interpreter present during interaction is "softened" by the use of expressions "unprofessional" or "unqualified." To give just one example, in 2015 the Irish Examiner reported a case of two British 
tourists murdered in Thailand, in which "the problems of using unprofessional translators to interrogate the two defendants" was described [Irish Examiner 2015], where the alleged "translators" were pancakes vendors, who spoke well neither of the languages they were supposed to mediate between [Miller 2015]. This raises the question, whether calling such language intermediaries "unprofessional translators" is not a linguistic abuse in itself, and one not less disturbing than the situations presented above. In the present article, however, cases like this one were not taken into consideration because, rightly or not, the researchers in translation studies use the term "non-professional interpreting and translation" themselves, as a widely accepted name for a new area of investigations that concentrates on "natural translation." Although at least some of scholars, probably sensing the possible sociolinguistic problem, introduce a new, less controversial concept of "language brokering" [see Antonini et al. 2017]. The idea is worth supporting, but in the meantime, a more pressing issue surfaces, and that is the apparently common misconception shared by the public that liaison interpreting is not a profession that requires adequate qualifications. It is something that anyone can do. Less like a nurse or a guide, more like a cook or a driver - an activity most of us dabble in from time to time, but rarely "professionally" or even for money. As a professional community, we need to consider if that is good enough.

The professionalisation of any human activity is a lengthy and complicated process. Creating schools, certifications, or even laws to establish a new occupation is not the end of this path. Without a wider, public understanding that a surgeon is someone who has successfully studied for a very long time, we would still see no difference between a barber and a true practitioner of medicine. Probably, when it comes to the social perception of liaison interpreters, it is not a process that can be rushed or sped up. Nevertheless, it is a problem that the translators' and interpreters' community should recognise, if not to protest loudly whenever the profession is being besmirched, then at least to stop ourselves from duplicating and spreading the common misconceptions. Not calling unprofessional language brokers "interpreters" or "translators" could be a good start. 


\section{Bibliography}

Antonini, R. et al. (2017), Non-professional Interpreting and Translation. State of the Art and Future of an Emerging Field of Research, John Benjamins, Amsterdam-Philadelphia, https://doi.org/10.1075/btl.129.

Flores, G. et al. (2003), Errors in medical interpretation and their potential clinical consequences in pediatric encounters, Pediatrics, January 2003, 111(1): 6-14, American Academy of Pediatrics, https://doi.org/10.1542/peds.111.1.6.

Gouadec, D. (2007), Translation as a Profession, John Benjamins Publishing Company, Amsterdam-Philadelphia.

Janikowski, P. (2012), "Dydaktyka thumaczenia ustnego a postrzeganie zadań thumacza", [in:] Maciej Ganczar, Piotr Wilczek, (eds), Rola tlumacza i przektadu w epoce wielokulturowości i globalizacji, Wydawnictwo Śląsk, Katowice.

Kubacki, A.D. (2012), Ttumaczenie poświadczone: Status, kształcenie, warsztat i odpowiedzialność tlumacza przysięgłego, Wolters Kluwer, Warszawa.

Phelan, M. (2001), The Interpreter's Resource, Multilingual Matters LTD Topics in Translation: 19, Clevedon-Buffalo-Toronto-Sydney.

Pym, A. (2012), On Translator Ethics. Principles for mediation between cultures, John Benjamins Publishing Company, Amsterdam-Philadelphia, https://doi. org/10.1075/btl.104.

Tryuk, M. (2007), Przektad ustny konferencyjny, PWN, Warszawa.

Tseng, J. (1992), Interpreting as an Emerging Profession in Taiwan - A Sociological Model, Unpublished Master's Thesis, Fu Jen Catholic University, Taiwan.

Wadensjö, C. (1998), Interpreting as Interaction, Longman, London-New York. Wilss, W. (1999), Translation and interpreting in the 20th century: focus on German, John Benjamins Publishing Company, Amsterdam-Philadelphia, https:// doi.org/10.1075/btl.29.

\section{Media sources}

Beitsch, R. (2016), "How bad translation by court interpreters can turn misunderstanding into injustice", PBS News Hour, [online] https://www.pbs.org/ newshour/nation/bad-translation-by-court-interpreters-injustice - 8.02.2021.

Berg, M. (2020), "Why Ellen DeGeneres Won't Be Cancelled", Forbes, [online] https://www.forbes.com/sites/maddieberg/2020/07/17/why-ellendegeneres-wont-be-canceled/?sh=51c0142d4aa9 -10.02 .2021 .

IMDb database: "The Ellen DeGeneres Show", [online] https://www.imdb.com/ title/tt9827080/?ref_=ttpl_pl_tt -10.02 .2020 . 
Irish Examiner (2015), "Translator use in tourist deaths case "flawed and unprofessional"”, [online] https://www.irishexaminer.com/world/arid-30697738. html - 10.02.2021.

Levine, D.S. (2020), "Ellen DeGeneres Called out Over Old Video Showing Her Chastising Young Translator Mid-Interview", popculture.com, [online] https://popculture.com/tv-shows/news/ellen-degeneres-calledout-video-showing-chastising-translator-interview/-10.02.2020.

Łępicka, J. (2015), “Tłumacze a dyplomacja, czyli Jimmy Carter i jego ogromna miłość do Polaków”, joannalepicka.pl/blog/, [online] http://joannalepicka.pl/ tlumacze-dyplomacja-czyli-jimmy-carter-jego-ogromna-milosc-polakow/ 8.02.2021.

Miller, M.E. (2015), "Case over Hannah Witheridge and David Miller's deaths on Thai island unravelling", The Sydney Morning Herald, [online] https://www. smh.com.au/world/case-over-hannah-witheridge-and-david-millers-deaths-onthai-island-unravelling-20150916-gjnigk.html - 10.02.2021.

Price-Wise, G. (2008), "Language, Culture, And Medical Tragedy: The Case of Willie Ramirez", Health Affairs Blog, [online] https://www.healthaffairs.org/ do/10.1377/hblog20081119.000463/full/ - 05/01/2021.

The Professional Interpreter (2015), [online] https://rpstranslations.wordpress. $\mathrm{com} / \mathrm{tag} /$ mistakes/ - 10.02.2020.

Wilson, S. (2019), "Translator at Japanese marathon under fire for calling African athletes 'cute chimpanzees", SoraNews24, [online] https://soranews24. com/2019/02/16/translator-at-japanese-marathon-under-fire-for-calling-africanathletes-cute-chimpanzees/ - 10.09.2020.

YouTube (2020), "Ellen SAYS WHAT to kid and translator?!?", [online] https:// www.youtube.com/watch?v=g_lUglL8rfQ - 9.02.2021.

\begin{abstract}
The aim of the article is to present some of the problems related to the professionalisation of interpreting from the perspective of the public misconceptions about this occupation. An analysis of three press releases published online shows, that the terms "interpreting" and "translation" are used quite often to describe any form of communication occurring between two languages, rather than a profession, even if no third, mediating party is present. This may suggest low social consciousness regarding liaison interpreting and a need to consider the public image during the professionalisation process of this occupation.
\end{abstract}


Keywords: liaison interpreting, professionalisation, public image

\begin{abstract}
Abstrakt
Analiza pewnych powszechnych nieporozumień dotyczących zawodu thumacza typu liaison

Artykuł ma na celu przybliżenie problematyki profesjonalizacji thumaczenia ustnego typu liaison z perspektywy szeroko rozumianej opinii publicznej i przedstawienie pewnych powszechnych nieporozumień związanych $\mathrm{z}$ tym zawodem. Analizie poddane zostają trzy teksty prasowe opublikowane w Internecie, w których dostrzegamy zastosowanie określeń „tłumacz” i „tłumaczenie” w odniesieniu nie do zawodu, a raczej do potocznego, bardzo szerokiego zjawiska mediacji międzyjęzykowej, niekoniecznie za pośrednictwem osoby trzeciej. Może to świadczyć o niskiej świadomości społecznej dotyczącej tłumaczenia ustnego oraz o potrzebie wzięcia pod uwagę kwestii wizerunku publicznego $\mathrm{w}$ procesie profesjonalizacji tego zawodu.
\end{abstract}

Słowa kluczowe: tłumaczenie liaison, profesjonalizacja, wizerunek publiczny 